\title{
Constitutional Culture or Ordinary Politics: A Reply to Reva Siegel
}

\author{
Robin West $\dagger$
}

Reva Siegel's lecture, Constitutional Culture, Social Movement Conflict and Constitutional Change: The Case of the de Facto ERA, ${ }^{1}$ explores the interaction between the courts and social movements in creating constitutional meaning. In the primary part of this response 1 focus my comments on Siegel's three major contributions: First, the historical explanation of the source of the Court's authority in the development of the socalled de facto ERA:; ${ }^{2}$ second, the articulation of a general, jurisprudential thesis regarding social contestation as a source of constitutional authority apart from text, history, and principle ${ }^{3}$ and third, the quasi-sociological descriptive account of the form social contest must take to be juris generative. ${ }^{4} 1$ find Siegel's historical interpretation, jurisprudential thesis, and sociological analysis compelling, and in this response 1 offer thoughts on how Siegel's basic thesis might be expanded and strengthened.

The subsequent part of this response raises some questions and doubts about Siegel's underlying invitation in this lecture: an invitation to social activists, whether or not legally trained, to participate more frequently and self-consciously in the umbrella of social processes commonly referred to as "popular constitutionalism." While we should worry-as the popular

Copyright (C) 2006 California Law Review, Inc. California Law Review, Inc. (CLR) is a California nonprofit corporation. CLR and the authors are solcly responsible for the content of their publications.

$\dagger \quad$ Professor of Law, Georgetown University Law Center. Many thanks to the participants at the Brennan Lecture at Boalt Hall, for thoughtful comments and conversations on the early draft of this reply.

I. Reva SiegeI, Constitutional Culture, Social Movement Conflict and Constitutional Change: The Case of the de Facto ERA, 94 CALIF. L. REv. I323 (2006) [hereinafter Constitutional Culturel.

2. Id. at I332-1340; I366-1414.

3. Id. at $1340-1350$.

4. Id. at 1351-66.

5. The major proponents of popular constitutionalism to date include LARRY KRAMER, THE People Themselves: Popular Constitutionalism and Judicial Review (2004) [hereinafter The People Themselves]; Mark Tushnet, Taking the Constitution away from the Courts (2000); and Lawrence Sager, Justice in Plainclothes: A Theory of American Constitutional 
constitutionalists do-about the Supreme Court's outsized role in the development of constitutional meaning, it does not necessarily follow that we should transport those constitutional modes of thought into our politics. Instead, the more sensible response to the hubris and over-reach of the Supreme Court's monopolization of constitutionalism in this culture may be to give ordinary politics long overdue respect. ${ }^{6}$ To do so, it might sometimes be wise to curb our inclination to cast political views and values in the framework of constitutional argument.

\section{I}

\section{Courts, Meaning and Social Contest}

\section{A. History}

The primary contribution of Siegel's lecture ${ }^{7}$ is both descriptive and historical, and of tremendous importance to understanding both the women's movement in the 1970s and the processes of constitutional change. Professor Siegel provides a way to make sense of a legal turn in our doctrinal development that is otherwise quite incomprehensible-the extension of constitutionally-based equality law to women. How, Siegel asks, did this doctrinal extension of equality law come to be promulgated by the Supreme Court at all during the I970s, given the state of equality law at the time? Even more consequentially, how did that turn come to be accepted by the rest of us, particularly in the face of the defeat of a constitutional amendment explicitly extending equality law to women and the political movement accompanying it? ${ }^{8}$

At the time of the doctrinal shift, the Constitution contained no text mandating equal rights for women. Additionally, through the course of the I970s the proposed Equal Rights Amendment of 1972 dramatically failed to garner sufficient state support to pass. ${ }^{9}$ From that failure the Court could

PRACTICE (2004). See generally James E. Fleming, Judicial Review Without Judicial Supremacy: Taking the Constitution Seriously Outside the Courts, 73 FordHaM L. REv. 1377 (2005) (commenting and criticizing contemporary popular constitutionalism); MaryBeth Lipp, Legislators' Obligation to Support a Living Wage: A Comparative Constitutional Vision of Justice, $75 \mathrm{~S}$. CAL. L. REv. 475 (2002) (arguing for a legislatively enforced constitutional obligation to provide a living wage); Cass Sunstein, The SECond Bill of Rights: FDR's Unfinished Revolution and Why We NeEd 1T More than Ever (2004).

6. I have argued elsewhere that another response to judicial monopolization of constitutional interpretation might be to seek to strengthen the obligation of legislators to follow through on their possible constitutional obligations, such as their obligation under the Fourteenth Amendment to affirmatively provide equal protection of laws. Although not at all inconsistent with the popular constitutionalism advocated by Kramer and others, the "legislated constitutionalism" 1 have advocated has a different focus: It aims to infuse our legislative lawmaking, rather than our popular politics, with specific constitutional mandates. See Robin West, Katrina, the Constitution, and the Legal Question Doctrine, 74 CHI.-KENT L. REV. 101 (2006).

7. Constitutional Culture, supra note 1, at 1332-40; 1366-1414.

8. Id. at 1324 .

9. Id. at $1378-79$. 
have easily inferred a lack of constitutional authority for women's equal rights. Indeed, with a little imagination the Court could have gone even further to infer a measure of constitutional authority for protection of women's traditional family role. ${ }^{10}$ Likewise, there was no clear authority for the Court to make this doctrinal extension pursuant to its representation-reinforcing powers of review, as ambiguously outlined in the famous Carolene Products ${ }^{11}$ footnote. As John Hart Ely argued during the 1970s, women are not a discrete and insular minority with artificially diluted voting powers, deserving and needful of a judicially-provided constitutional boost to ensure their voices are heard in representative processes. ${ }^{12}$ After all, women vote, are evenly distributed through the population, suffer no obvious impediments to organizing, and cannot fairly be described as the objects of scorn, prejudice, or dehumanization. In short, if this power of judicial review is meant to clear the channels of political change of illicit impediments to the representation of disempowered groups, there is no reason for it to do so on behalf of women.

Nor did the Court's common law-like power of constitutional interpretation clearly point in the direction of an extension of these rights to women. If discrimination against women is analogous to discrimination against Blacks, then extension of equality rights to women might be justified by reference to stare decisis. ${ }^{13}$ Legal justice, stare decisis, and the rule of precedent all demand that if $\mathrm{x}$ is like $\mathrm{y}, \mathrm{x}$ should be decided the same way as $y$. Indeed, the Court eventually found the situations of women and Blacks sufficiently analogous. ${ }^{14}$ Consequently, women cannot be denied the protection the law bestows, and cannot be discriminated against by

10. For example, Justice Scalia's suggestion in Michael H. v. Gerald D. that the "liberty" protected by the substantive due process clause should be interpreted as protecting the liberty of individuals to enjoy the benefit of traditional cultural constructs-such as traditional marriage, or traditional gender roles - could surely have been employed in such a way as to invalidate state or federal law purporting to extend Title VII or Title LX to women. 49I U.S. 110, 123 (1989).

11. United States v. Carolene Prods. Co., 304 U.S. 144, 152 n.4 (1938) (arguing that the Court should provide heightened scrutiny of legislation that seemingly adversely impacts the interests of discrete and insular minorities).

12. John Hart Ely, The Wages of Crying Wolf: A Comment on Roe v. Wade, 82 YALE L.J. 920 (1973).

13. For full explications of this model of constitutional common law adjudication see, David A. Strauss, Common Law Constitutional Interpretation, 63 U. CHI. L. REv. 877, 879-91 (1996); see also SUNSTEIN, supra note 5, at 152-53 ("American constitutional law is, to a considerable degree, a form of common law based on analogical reasoning."); CAss R. SUnStein, ONE CASE AT a TIME: JUdicial Minimalism on the SuPREme CourT (1999); Cass R. Sunstein, Foreword: Leaving Things Undecided, 1 I0 Harv. L. Rev. 4 (1996).

14. Reed v. Reed, 404 U.S. 71 (1971) (striking a statute providing a tie-breaking rule that a son would be preferred over a daughter to administer a deceased parent's estate); Frontiero v. Richardson, 411 U.S. 677 (1973) (striking a rule permitting a serviceman from claiming his wife to be a "dependent" without regard to whether she is in fact dependent, but not allowing a servicewoman to do so); Craig v. Boren, 429 U.S. 190 (I976) (striking a statute prohibiting the sale of beer to males under twenty-one and to females under the age of eighteen). 
state actors. The argument for equality by analogy, however, openly begs the question. Sex is not like race in any mechanical kind of way. Women are not a numerical minority. While some Black women have suffered a history of race-based enslavement, segregation, and violent debasement in this country, White women have not. Rather, a large number of women enjoy and have long enjoyed a status within the traditional home-a position honored by their communities and passionately desired by some women themselves. Although long denied the franchise, by the time of the judicial transformation examined in Siegel's lecture, women had been voting for half a century. Finally, by the 1970s women had protections against discrimination in employment and education. ${ }^{15}$ So, how did race and gender become analogous in the Court's imagination, thereby justifying its extension of the "antidiscrimination principle" to sex? And how did the rest of us come to accept the legitimacy of this extension?

Siegel's lecture gives us an entirely original, nuanced answer as to how the Court legitimized the extension of equality law to women. ${ }^{16}$ Siegel argues that the constitutional meaning the Court utilized was forged not from precedent or text, but from a decade of social debate, protest, and agitation, all of which took place outside the Court's walls. ${ }^{17}$ Specifically, Siegel posits that the Court came to the de facto ERA on the basis of a meaning of equality, which emerged from the struggles for and against the passage of the Equal Rights Amendment during the 1970s. On one side of this struggle was the women's liberation movement, continuing a centurylong history of American feminist activism seeking to create a world in which women have full rights of equal citizenship. For the women's movement of the 1960s and 1970s, passage of the ERA was viewed as central to attaining equal citizenship. ${ }^{18}$ For them, equal citizenship involved more than protections against workplace and state discrimination. It also required universal, publicly-funded childcare-so as to promote both sex equality in public life and in employment-as well as legally recognized reproductive rights and greater paternal and communal responsibility for raising children-so as to free women from the non-consensual and

15. Title V1I of the Civil Rights Act of $1964 \S 703$ (a), 42 U.S.C. $\$ 2000$ e (2000) (forbidding discrimination in employment on the basis of sex); Title IX of the Educational Amendments of 1972, 20 U.S.C. $\S 1681$ (a) (2000) (forbidding discrimination on the basis of sex in any education program or activity receiving federal financial assistance).

16. There are other possible historical accounts of how and why the Court embraced a formal equality model for navigating the waters of women's status. Mary Becker argues that by the time of the major constitutional cases, Congress had extended Title VII to women, with an implicit embrace of formal equality at its heart. The Court, on this view, was following Congress's lead. See Mary Becker, The Sixties Shift to Formal Equality and the Courts: An Argument for Pragmatism and Politics, 40 WM. \& MARY L. REv. 209 (1998). This view is not incompatible with the view argued in Siegel's lecture; the Court might have been influenced by Title VII and by the social contestation Siegel describes.

17. Constitutional Culture, supra note 1, at 1366-89.

18. Id. at 1370-78. 
illiberal use of their bodies for both the nurturance of fetal life and the work of subsequent unwanted, unplanned motherhood. ${ }^{19}$ These feminists hoped passage of the ERA would eventually prompt recognition of the centrality of universal and state funded childcare and full reproductive rights to women's equality.

On the other side of the struggle were those who campaigned against the ERA-whom I will call traditionalists. Anti-ERA activists put forward their own understanding of what it means for women to be equal citizens. ${ }^{20}$ Traditionalists resisted the ERA not on the basis of an explicit resistance to women's equality, but rather out of a passionate commitment to a particular way of life. Mothers and wives in middle-class White households became the foot soldiers in the campaign to defeat the ERA based on the belief that the proposed amendment threatened the traditional role of women. Anti-ERA women did not want "choice," liberation, or freedom from household responsibilities. After all, these women garnered respect, honor, affection, gratitude, and security precisely by virtue of the strictures of their household work. They embraced the twenty-four hour job of childraising and house keeping; accepted their un-chosen, fated pregnancies brought on by marital intercourse without contraception; and devoted themselves to the universal, mundane task of cleaning and cooking quite consciously at the cost of pursuing other forms of challenge. ${ }^{21}$ For traditional women, these restrictions were neither demeaning, nor subordinating. Nor were they evidence of internalized self debasement. ${ }^{22}$ Instead, the restrictions were the sacrifices central to the core moral meaning of a traditional life: a life rewarded by the domestic fulfillment of loved children, a satisfied husband, and a well-run household.

At the time of the women's movement, that core moral meaning was primarily threatened not only by the ERA itself, but by the physicality of the traditionalists' ERA-besotted daughters. Those daughters with their unkempt hair; unattractive, unflattering clothes; unshaven legs and underarms; disdain for make-up, heels, bras, and nylons; and above all else, their birth control pills; cruelly evidenced both their open sexuality and their conscious decision not to mother. To the mothers of these daughters, this

19. Id. at $1373-77$.

20. Id. at 1389-94.

21. Kristin Luker has provided an excellent account of the underlying values and consciousness of the anti-abortion movement which emphasize that lack of choice is central to the value of and respect garnered by the traditional woman's mothering and housekeeping. 1 would suggest the same psychology likely underlies the anti-ERA movement Siegel describes. KRISTIN LUKER, ABORTION AND The Politics of Motherhood 205-208 (1984). Andrea Dworkin suggested an overlapping but somewhat different interpretation of the psychology of this movement. Dworkin argues that both the ERA and the Abortion Rights movements were alarming because they threatened to undermine a dependant woman's source of economic security. ANDrEa DWorkin, Right-Wing Women: The Politics of Domesticated Females (1983).

22. LUKER, supra note 21 , at $158-75$. 
was more than an insult; it was an explicit rejection of their own carefully cultivated traditional way of life. The ERA symbolized and expressed that profound generational rejection.

Thus, the traditionalists' resistance to the ERA is not difficult to understand. Imagine a mother who, when asked about the unfinished $\mathrm{PhD}$ dissertation, the abandoned nursing career, or the easels in the attic, responds: "I gave it all up for you. You are my fulfillment. My sacrifice of all of that, in order to raise you, is who I am. That is the value of me; that is why I'm worth something." The daughter, for whom this was sacrificed, then publicly and privately defines herself, her politics, and her passion by reference to a movement advocating for women to pursue the very things the mother defined herself by forsaking. Whereas the mother foreswore contraception, leaving her reproductive fate in God's hands, her daughter marched for the right to use contraception. Whereas the mother embraced her husband's support and gratitude in return for her sacrifices, her daughter agitated for the right to demand a paycheck meant to take the place of a husband's support. The mother's daughter, in effect, defines herself not just as "not you," but against and in negation of her mother. It is from this tremendous loss and searing generational insult the anti-ERA movement emerged, spear-headed by Phyllis Schlafly. Anti-ERA women resisted with passion and intelligence what they perceived as a massive, reckless, uncaring assault on a precious way of life. ${ }^{23}$

If read generously, the heart of that counter-movement provides glimpses of a competing understanding about what "equal citizenship" meant to women. Siegel's account of the anti-ERA forces suggests the contours, if not the details, of that contrasting understanding: To the traditionalists, equal citizenship clearly did not imply, require, or permit abortion rights, birth control pills, universal daycare, women in the military, lesbianism, or unisex bathrooms. ${ }^{24}$ Rather, it merely required a floor of formal antidiscrimination rights. Beyond that, traditionalism, not feminism, is what was necessary to protect and ensure the equal respect women need to live out their lives in safety and with dignity in the domestic sphere. ${ }^{25}$ Indeed, to protect and ensure equal respect, reproductive choice must be taken from the table: The fatedness of reproduction was central, not peripheral, to the equal respect women garnered through living out their traditional roles. Under the same logic, any state interference with child rearing was seen as a threat to equal respect for women. Universal, publicly funded childcare on a public school model was quintessentially disrespectful of women's distinctive role in family life. It was the antithesis, not the embodiment, of women's equal citizenship. Thus, the two demands made by

23. Constitutional Culture, supra note 1, at 1389-1403.

24. Id.

25. Id. at 1403-07. 
early ERA proponents - universal child care and reproductive freedom-were precisely what the anti-ERA forces viewed as most threatening to women's traditional role, and hence most threatening to women's rights to dignity and equal respect.

Siegel's lecture nicely shows that from the ashes of this battle arose a newly forged constitutional understanding, built on a fragile consensus acceptable to both sides, of what it means for women to enjoy equal rights with men. The juris generative meaning of this fragile consensus was: Where a woman is similar to a man in aptitude, intelligence, ability, strength, and fortitude, she must be treated equally; that is, she may not be discriminated against or wrongly assumed to be different out of deference to an overdrawn stereotype. This shared constitutional understanding, Siegel argues, became the ground for a new way of being a woman, and therefore a new way of being an American, an individual, and an equal citizen. Over a relatively short period of time this shared understanding became the heart of the de facto ERA.

Siegel's major historical thesis is that this understanding of what is now called formal equality-where women are the same as men they must be treated the same - was the product of social struggle, not judicial creativity: the Court embraced it but it did not invent it or discover it in precedent. It is worth noting, although Siegel does not dwell on it, that if her characterization of this constitutional contestation in the public sphere is correct, each side gave something up to forge this new constitutional meaning. Indeed, both sides may have given up too much in exchange for the consensus reached, and if so, it is not at all apparent which side (if either) won the battle. First, as Siegel meticulously shows, the women's movement gave up (through a series of concessions) its robust understanding of what equality and citizenship require: universal child care, access to contraception, and available, safe abortion. More fundamentally, though Siegel does not put it this way, the women's movement gave up their early claim that the state must invest resources in assisting women's equal participation, representation, and voice in public life so that participation would not come at the sacrifice of responsible parenting. With universal childcare and responsible reproductive autonomy as the fruits of the government's investment, there is no longer a need for a maternal role so all-encompassing as to preclude work, politics, or broader civic life. The burden of parenting can be planned and shared between equals. The specter of fear, a constrained public life, and the forced domesticity that accompanies both willed and unwilled pregnancies is erased.

Though not explicit in Siegel's article, the anti-ERA forces gave up at least as much in battle. It lost the "no exit" dimension of traditionalism. By virtue of the antidiscrimination principle at the heart of the compromise, the woman or girl who has the wherewithal and desire to forge the 
nontraditional life - to go to law school, fight fires, tend bar, and so oncannot be refused the right to do so. The exceptional woman may not be discriminated against, assumed to be what she is not. She has an option; she has an exit. She may choose to live a traditional life, but it is not her fate to do so. There is a world of difference between a choice and a fate. We submit to tradition, as we do to fate, and we do so more or less graciously. We choose, on the other hand, because we have determined that the choice is a good one.

Thus, feminists lost their demand for state investment in women's equality through funded childcare and full reproductive rights, and traditionalists lost their insistence on the necessity of the traditional role. Cut both away, and what remains is the antidiscrimination principle, or the de facto ERA. Thus, this de facto ERA lies at the intersection of the contrasting visions of traditionalists and feminists. But look at what the result is not. It is not a constitutional meaning embracing a new paradigm of childraising, work, and political participation. Nor is it embracing a paradigm that invests the full dignity of citizenship in the mantle of the traditional woman. Rather, it is an exit option: Exceptional women can opt out of traditionalism, and when they do so, they must be treated similarly to men. Though women promulgated both original demands, the resulting principle was ultimately resonant with neither movement.

The de facto ERA is fully resonant with a type of society that I will call the "republic of choice." By this I mean a republic committed to the proposition that value is created not through embracing tradition and not through social equality, but rather through the operation of individual, autonomous decision making. First, the de facto ERA is highly individualistic; not communitarian in the least. The exceptional woman may work if she chooses, but the community will not raise her child if she opts to do so. It is simply a choice she has made. Second, the de facto ERA is not at all traditionalist. The traditional woman may continue to stay at home but will receive no benefit or security from a shared communal understanding that it is her lot in life to do so. Similar to the exceptional woman, this lifestyle is simply a choice the traditional woman has made. She gets and presumably needs no support or respect from the rest of us.

This new constitutional meaning, as it resonates with the "republic of choice," unearths some of the long-lost common ground between the ERA advocate and her estranged mother. Now they share something. They both chose their fate and consequently share a common and unexpected destiny: They are left to their own privatized devices. Neither of them will get, nor can expect, any help from society - either officially through the state or unofficially through tradition-by virtue of choice.

The compromised consensus between liberation and tradition is, in essence, the de facto ERA. By the time the Court promulgated the de facto 
ERA, its application to women did not feel particularly unfamiliar: though the principle constituted a rejection of state backed equality and a rigid traditionalism, it found common ground in an individualistic ethic that had come to permeate American culture. Siegel concludes from her historical analysis that the missing authority for the Court's extension of antidiscrimination to women, otherwise so anomalous, came from this social struggle over the ERA and its eventual resolution. Her argument is thoroughly novel and convincing.

\section{B. Social Contestations as a Source for Constitutional Authority}

Siegel's second major contribution in this lecture is the underlying suggestion that social contestations and movements could be a source of constitutional authority. If Siegel is right-this is not just a one-time historical anomaly - then we should be able to think of other cases fitting the same epistemological pattern. The de facto ERA appears in Siegel's lecture as an example of what she believes is a larger pattern. Though Siegel does not suggest any additional plausible candidates from the case law, she does provocatively indicate that constitutional contestation might provide the missing link in the migration of "civil union" from the pariah of traditionalists opposed to homosexuality to the accepted alternative to "gay marriage." 26 However, since the Court has not held that civil unions are constitutionally required, this compromise is not yet an example of judicially accepted constitutional meaning garnered from social contestation. The absence of current plausible candidates in the lecture raises the question of whether there are other leaps or gaps in the Court's constitutional case law that can be explained by reference to the same socio-legal development: social contestation, to hard fought consensus, to judicially pronounced norm.

I would suggest that Eisenstadt v. Baird $d^{27}$ may be read through this lens. In that case, the Court held that single persons have the constitutional right to use birth control. The case was an extension of Griswold $v$. Connecticut, ${ }^{28}$ where the Court held that the Constitution protects the right of married partners to use birth control. Eisenstadt's rarely challenged and utterly unelaborated extension of Griswold is mysterious. It looks as illegitimate as the extension of the antidiscrimination principle to women. After all, Griswold was decided on the basis of the sanctity of marriage and family. ${ }^{29}$ Hence, the case emphasizes the importance of maintaining the

\footnotetext{
26. Constitutional Culture, supra note 1, at 1414-18.

27. 405 U.S. 438 (1972).

28. 381 U.S. $479(1965)$.

29. Griswold, 381 U.S. at 486 ("We deal with a right of privacy older than the Bill of Rightsolder than our political parties, older than our school system. Marriage is a coming together for better or for worse, hopefully enduring, and intimate to the degree of being sacred."). In his concurring opinion, Justice Goldberg noted:
} 
family as the primary locus of authority, even when the family's authority comes into conflict with the state. ${ }^{30}$ The line of cases on which Griswold rests not only seek to protect family - and marriage as the social institution within which procreation and child-raising can proceed unimpeded by the state-but also seek to protect the separate authority of married parents-a "separate sovereignty." Thus, family and marital privacy are valued in these pivotal cases only because they are preconditions to the marital unit maintaining authority over the formation and cultivation of a family without interference by the state.

Yet, in an unheralded about-face, Eisenstadt gives individuals a way to enjoy sex and avoid family by protecting the right to be free from the ties of marriage and family that Griswold valorized. ${ }^{31}$ In Eisenstadt, the "right" and "authority" to raise children became the right to have sex without fear of reproductive consequences. How can this conclusion follow from the rationale in Griswold? Eisenstadt not only does not follow the rationale of Griswold; it directly undercuts it. The individualized right to sex without reproductive consequences is an effective reversal of the reasoning underlying Griswold, not an extension of it. ${ }^{32}$ How did this happen with so little fanfare?

Professor Siegel's remarkable methodological insight about the processes of constitutional change might help solve this mystery. Perhaps Eisenstadt would be best explained by reference to the sexual revolution underway at the time it was decided, the resistance to that revolution by advocates of sexual modesty, the social contestation between these

Although the Constitution does not speak in so many words of the right of privacy in marriage, I cannot believe that it offers these fundamental rights no protection. The fact that no particular provision of the Constitution explicitly forbids the State from disrupting the traditional relation of the family - a relation as old and as fundamental as our entire civilization-surely does not show that the Government was meant to have the power to do so.

Id. at $495-96$.

30. Meyer v. Nebraska, 262 U.S. 390, 399 (1923) (stating that liberty "denotes . . the right of the individual ... to marry, establish a home and bring up children, to worship God according to the dictates of his own conscicnce"); Picrce v. Soc'y of Sisters, 268 U.S. 510,534 (1925) (stating that "liberty [includes the right to] direct the education of children"); Poe v. Ullman, 367 U.S. 497,553 (196I) ("Adultery, homosexuality and the like are sexual intimacies which the State forbids altogether, but the intimacy of husband and wife is necessarily an essential and acceptcd feature of the institution of marriage, an institution which the State not only must allow, but which always and in every age it has fostered and protected. It is one thing when the State exerts its power either to forbid extra-marital sexuality altogether, or to say who may marry, but it is quite another when . . . it undertakes to regulate by means of the criminal law the details of that intimacy.") (Harlan, J., dissenting).

31. Thus in Eisenstadt, the Court states that what is at stake is the decision to procreate. Eisenstadt, 405 U.S. at 453 ("If the right of privacy means anything, it is the right of the individual, married or single, to be free from unwarranted governmental intrusion into matters so fundamentally affecting a person as the decision whether to bear or beget a child.").

32. See Pierce, 268 U.S. at 534 (holding that laws requiring students to attend public school violated the Fourteenth Amendment by depriving parents and guardians of the liberty to educate their children); see also Meyer, 262 U.S. at 399; supra note 30. 
positions, and then, finally, an uneasy compromise between them, resulting ultimately in the expression by the Court of a principle of non-marital sexual privacy. The principle embraced by the Court in Eisenstadt-that unmarried individuals have a right to use contraception-looks like something that is left when two worlds collide. This is not unlike the formation of the de facto ERA. On one side, sexual liberationists insisted on non-marital and decidedly public expressions of sexuality. They made posters directing readers to "Make Love, Not War" and informing them that "Girls Say Yes to Boys Who Say No" (yes to sex, no to the war); participated in Haight-Ashbury's festivals of love and San Francisco's "Free Love Movement"; went to Woodstock; supported the Stonewall riots; celebrated gay life and gay sex; watched the Broadway rock musical Hair with its public nudity; and so on. Sex, so the implied argument of all of this "sex affirmation" went, is itself of positive value, in all venues and all configurations. The less inhibited-such as inhibition by the prospect of childbearing - the better. On the other side, the advocates of sexual modesty believed that sex has positive moral value only when it is marital, procreative, and private. Otherwise, sex is immoral.

This conflict over the moral value of sex shared characteristics with the battle over the ERA. The Free Love movement also tore families apart. It threatened public order and decorum, and made a mockery of deeply held religious beliefs. Like the ERA, traditionalists view the Free Love movement as threatening a way of life and an understanding of femininity. It undermined girlhood and womanhood, in which sexual modesty is essential for the delicate bargaining between the sexes; bargaining that could result, or should result, in a stable home life with a productive husband and father, a dependent but supported wife, and well-behaved children. Without sexual modesty, this could all fall apart; without the bargaining over withheld goods, any resulting settlement would be sure to lack substance. ${ }^{33}$

Perhaps "sexual privacy" of the sort defended in Eisenstadt provided an acceptable compromise to this debate. Again, both sides gave something up. Sexual liberationists gave up the publicity-public sex, public nudity, public celebration of sexual deviance - and with it the underlying argument that sex has some positive value beyond marriage and children. Modesty proponents gave up the requirement of marriage. What remained is a right to non-marital sexuality so long as it is in private-a nod to modesty, and a nod to liberation. If we follow Siegel's logic, it is not surprising that the Court adopted and protected this understanding of sexual privacy, first in Eisenstadt and later in Lawrence. ${ }^{34}$ This principle, derived from social

33. Luker's history explores the view of sex, and sexual modesty, typically held by pro-life activists. See LuKER, supra note 21, at 163-75.

34. Lawrence v. Texas, 538 U.S. 918 (2003) (holding that laws criminalizing homosexual sodomy are unconstitutional). 
contestation but then disingenuously articulated by the Court as a natural extension of prior case law, became a Griswold-based right to sex-forpleasure restricted to the private sphere, with no publicly understood value whatsoever. Despite its apparent doctrinal illegitimacy, there has been little to no public response to the Eisenstadt ruling.

Other examples could be examined, and 1 am sure it would be worth our while to do so. Suffice it to say, Siegel has introduced a disciplined subfield of legal-cultural studies: the study of how cultural and political contestation over equality and liberty eventually impact constitutional law and constitutional meaning. With this analysis, she has opened the door to a large room that others will certainly enter.

\section{Sociological Implications}

Finally, Siegel's lecture suggests the sociological contours of how this alchemical process works, not just in the context of gender, but also more broadly. ${ }^{35}$ How do conflicting worlds in social contest yield compromises capable of generating constitutional meaning? Siegel suggests this phenomenon occurs when adverse parties articulate, claim, and then recast our constitutional narratives from the past. ${ }^{36}$ These cultural constitutional claims are not unbounded; they do have to "fit." However, it is not precedent that the popular constitutional claim must fit with so much as it is constitutional myth. In other words, the constitutional claim made by the social activist on behalf of women - the dignity of the traditional life, for change in the workplace, or for the value of non-reproductive sex - must fit within our popular constitutional story as it has developed to date. Otherwise it will fail to gain traction, unite us, or speak to us all. Unless such a claim "speaks to us all," it truly has nothing to offer, least of all to antagonists with conflicting visions.

Further, if Siegel's sociological claim is right-that social activists must offer constitutional interpretations that cohere with our past in order for a compromised principle to gain constitutional meaning-then the fit requirement ought to raise some red flags about the value of the entire enterprise of seeking constitutional meaning, at least for political progressives and outsiders. When social antagonists cast conflicting visions in constitutional terms, they participate in a process that is inescapably hegemonic. Although she does not note it, the processes of popular constitutionalism, as Siegel describes them, resemble nothing more than the "parlor game" metaphor Ronald Dworkin famously introduced into our understanding of the "integrity" of adjudicated constitutional law. Dworkin suggested that each participating judge in the adjudicative process is like a

35. Constitutional Culture, supra note 1, at 1340-66.

36. Id. at 1352-62. 
participant in an imaginary parlor game..$^{37}$ The object of the parlor game is to write a novel; the object of constitutional adjudication is to write a decent body of law. Each actor, including each participant in the game (or each judge in the adjudicative process) must read what has been written and then compose an additional chapter (or case) to push the story line (or body of doctrine) along, while following logically from what came before. False starts, jagged edges, irrational plot twists, and untoward interventions into the flow of the story will be left on the cutting room floor in the process. What remains will be a story (or a body of law) that unfolds logically, adheres, and holds the center; but more importantly, what remains is a narrative pre-ordained in the first chapter. There may be unexpected turns, but there is nothing that in retrospect truly counts as a new beginning.

While it is too early to tell how this understanding of constitutional change operates outside the courts, it is possible that as social advocates take up constitutionalism as the vehicle within which to couch their arguments, they are also joining the parlor game. Their constitutional arguments, whether made inside or outside of court, must fit the ongoing constitutional storyline. Outside the courts the storyline may not be dominated by judicial precedent. Nevertheless, there is a story into which new developments must logically fit. It is not clear from Siegel's thesis whether the requisite "fit" is tighter or looser than that required inside the courts. Yet, the "prior chapters" continue to constrain future development. The means by which they do so, however, remain for others to explore.

Siegel's contribution in this lecture is three-fold. It explains the odd legitimacy of the court's gender equality jurisprudence, it introduces a form of cultural-legal studies-the study of how cultural contestation can produce constitutional meaning later ratified by courts-and it puts forward a plausible theory regarding how such constitutional meaning is forged-through the mutual acceptance and importation of unifymg constitutional narratives by cultural antagonists. The de facto ERA, authored by Herma Hill Kay, Wendy Williams, Phyllis Shlafly, Sam Erwin, Susan Ross, and others, is an entirely fitting example of the general pattern Siegel aims to uncover. It is hard to imagine what could have better meshed with our constitutional story of an individualist empire of choice other than the de facto ERA, with its insistence on individual rather than collective responsibility and individual rather than traditional determinants of one's fate.

37. Ronald Dworkin, How Law is Like Literature, in A MatTer of Principle 146-66 (1985). 
II

\section{NORMATIVE IMPLICATIONS}

In this part I will suggest one important normative implication of Siegel's lecture. Siegel's historical, jurisprudential, and sociological claims imply an invitation to social activists to explicitly create constitutional meaning out of the common denominator of their disputes. As Siegel demonstrates in her explanation of the de facto ERA, political actors have made successful constitutional claims on the community beyond what the Court previously held that were ultimately embraced by the Court. ${ }^{38}$ And if it was done once, it just might be done again. Social and political advocacy could potentially benefit from this sort of popular constitutionalist enhancement. Rather than simply urge a cause, position, or reform, social activists could constitutionalize those commitments and politics. This has the potential to enhance the political success of social movements and enrich our constitutional traditions on and off the Court.

The invitation is extremely tempting and even seductive. Let me give an example: If constitutional advocacy outside the courts can be the source of accepted constitutional meaning, then insisting, as I have done in a recent piece, that local, state and federal governments' failures in the preparation for and aftermath of hurricane Katrina-as well as the unaddressed poverty and its racist determinants within the City of New Orleans that those failures unmasked-are collectively the greatest constitutional travesty since the advent of Jim Crow inight actually be "juris-generative" rather than just "cranky." 39 After all, as I have argued, under the Fourteenth Amendment the government seemingly has an explicit affirmative duty to protect all citizens equally against the evils of natural catastrophe, private violence and racism, and lethal impoverishment resulting from centuries of private, violent racism. ${ }^{40} \mathrm{I}$ "can't help"41 but believe that is not only the true and deep meaning of the Equal Protection Clause; but it is also the true and deep meaning of the social contract. It is the nastiness, brutality and mortality that prompt us to enter civilization in the first place,

38. Constitutional Culture, supra note 1, at 1403-40.

39. Constitutional Culture, supra note 1, at 1362. Siegel distinguishes here between juris generative popular constitutional claims that persuade and claims made by cranks and utopianists that fail to do so.

40. Jacobus TenBroek first argued that the rights protected by the Fourteenth Amendment are entirely positive, by reference both to the untortured meaning of the language-that no state may deny equal protection of the laws, implies, if we remove the double negative, that every state must grant equal protection - and by reference to the history of the clause. The one uncontested core meaning was that states have a positive duty to protect all citizens' natural rights, including the natural right against private violence, and the U.S. Congress has an obligation under Section Five of the Fourteenth Amendment to ensure states uphold this duty. JaCoBus TENBroek, EQUal Under Law 237 (1965).

41. The phrase is Holmes's, the sentiment, obviously, is not. Holmes described his basic moral beliefs as those he "could not help" but believe. Holmes, Natural Law, 32 HARV. L. Rev. 40 (1918). 
or settle for the deal once we find ourselves born into it. ${ }^{42}$ Yet currently the Constitution-as expounded by the Court since passage of the Fourteenth Amendment - does not protect positive rights. In fact, it does not impose any affirmative duty on legislators to use the law to protect people against hardship, crime, or natural disaster. ${ }^{43}$ Nor does it recognize private racism or poverty as within its purview. I cannot help but know all that. But I also cannot help but know what Siegel's work very nicely confirms: The Constitution as expounded by the Court is not the only Constitution that governs us. Siegel's work, intentionally or not, invites us to explore the ways the Constitution might speak to us and through us outside the confines of the Court's reading, including the constitutional meanings the Court has censored. She deserves thanks for inviting our participation in such a grand project. That said, it is not clear whether we should accept the invitation without first considering four specific reservations.

The first reservation is entirely result-oriented. Siegel's description of the actual content of the de facto ERA does not suggest grounds for a thundering endorsement. The de facto ERA basically incorporates what is now called a model of "formal equality." 44 This model has its well-known drawbacks. ${ }^{45}$ I stand with the suffragists and the early ERA activists as

42. The phrase is taken loosely from Hobbes. Thomas Hobbes, The Leviathan 90, 121 (Richard Tuck ed., Cambridge Univ. Press 1996) (1651).

43. See San Antonio Indep. Sch. Dist. v. Rodriguez, 411 U.S. 1 (1973) (no right to a publicly financed education; no right to an equally funded education); Harris v. McRae, 448 U.S. 297 (1980) (no right to publicly funded abortions); Bowers v. DeVito, 686 F.2d 616, 618 (7th Cir. 1982) ("[T] here is no constitutional right to be protected by the state against being murdered by criminals or madmen. It is monstrous if the state fails to protect its residents against such predators but it does not violate . . any ... provision of the Constitution. The Constitution is a charter of negative liberties; it tells the state to let people alone; it does not require the federal government or the statc to provide services, even so elementary a service as maintaining law and order."). Scholars have contcsted this characterization of the Constitution (and of the Fourteenth Amendment in particular) for decades, but have not made a dint in judicial interpretation of the phrase. See, e.g., Laurence H. Tribe, COnstitutional Cholces 246-66 (1985); Steven J. Heyman, The First Duty of Government: Protection, Liberty and the Fourteenth Amendment, 41 DUKE L.J. 507 (1991); Susan Bandes, The Negative Constitution: A Critique, 88 MiCH. L. REv. 2271 (1990); TenBroek, supra note 40; Robin West, Response to State Action and a New Birth of Freedom, 92 GEO. L.J. 819 (2004).

44. See, e.g., Mary E. Becker, Prince Charming: Abstract Equality, 1987 SUP. CT. Rev. 201 (1987); Catharine A. MacKinnon, Reflections on Sex Equality Under Law, 100 YALE L.J. 1281 (1991); Ruth Colker, An Equal Protection Analysis of United States Reproductive Health Policy: Gender, Race, Age, and Class, 1991 Duke L.J. 324 (1991).

45. Formal equality (like its doctrinal cousin, color-blindness) at best gives a minimal boost to the disadvantaged group that is already most like the dominant group. At worst, it can backfire against the interests of those on whose behalf equality was urged. Most of the time it will simply be irrelevant to the end of gender-based domination. See Becker, supra note 44, at 247 (arguing that formal equality "cannot ... ensure that jobs are structured so that fernale workers and male workers are equally able to combine wage work and parenthood" and that "women, especially ordinary mothers and wives, have been harmed by the changes effected to date by the movement towards formal equality"); Mary $\mathrm{E}$. Becker, Commentary, Obscuring the Struggle: Sex Discrimination, Social Security, and Stone, Seidman, Sunstein, \& Tushnet's Constitutional Law, 89 CoLuM. L. Rev. 264, 276 (1989) (arguing that "the major problem from the perspective of women's inequality is not, as the cases suggest, that the 
Siegel describes them on their core vision. Equality, when reduced to formal equality, and the latter reduced to an antidiscrimination principle without universal and publicly funded childcare, reproductive autonomy, and freedom from fear for the safety of one's dependents in the home, workplace and street, is a pale imitation of the real thing. The danger is that the constitutionalized, de facto ERA might make it harder-not easier-to obtain the real pre-conditions of equality.

The second reservation goes to the "legitimation costs" of apparent legal reform-the patina of justice a successful reform paints over the deeper structural injustice, for which piecemeal reform efforts are illequipped to address. ${ }^{46}$ The serious legitimation costs to the de facto ERA deserve more than a mention. The de facto ERA rests solidly on an individualist ethic. There are problems with this ethic extending well beyond gender. It takes a village to do a lot more than just raise a child. It takes collective cffort at all levels of government to save and protect lives in the wake of a hurricane. It takes coordination, foresight, and substantial resources to transport the aged, poor, infirm, and newborn to high ground and out of harm's way. It takes immense collective intelligence to keep the air and water clean and the earth habitable. It takes collaborative government effort to educate the next generation, as well as provide for the health care, shelter, and sustenance of our weakest citizens. These projects cannot be left to markets or the individual choices of heroic actors, even if those choices are unburdened by prejudice, stereotype, or bias. Traditionalists and reformers both know this, yet as shown by the de facto ERA, both chose to settle for a principle based on individualist ethic. Unchecked by tradition or collectivity, this ethic has the potential to threaten much of the real value in cooperative life.

The third reservation concerns the fact that Siegel's history does not address what is likely the dominant popular constitutional narrative of our time. The constitutional meanings that have emerged from popular social movements over the past thirty years have at best rested on an

\footnotetext{
social security system has treated the atypical woman differently from a similar man, but rather that it gives less effective old age financial security to typical women than to typical men"); Ann Freedman, Sex Equality, Sex Differences, and the Supreme Court, 92 YALE L.J. 913 (1983) (arguing that the normative question regarding the role gender should play must precede the striking of gender specific statutes); Sylvia A. Law, Rethinking Sex and the Constitution, 132 U. PA. L. REv. 955, 1007 (1984) (arguing that equality doetrine should not ignore women's distinctive experiences of pregnaney, abortion, reproduction and creation of another human being); Christine A. Littleton, Reconstructing Sexual Equality, 75 CALIF. L. REV. 1279 (1987) (arguing that equality law glorifies abstraet principle); Catharine A. MacKinnon, Toward A Feminist Theory of the State 220-45 (1989) (arguing that both the sameness approach of formal equality and the difference approach advocated by some feminists rest on a liberal denial of the subordination of women to men's interests).

46. For examples of the role of law in legitimating injustice, see Robert W. Gordon, New Developments in Legal Theory, in The Politics of Law: A Progressive Critique 281 (David Kairys ed., 1982); Peter Gabel \& Jay M. Feinman, Contract Law as Ideology, in The Politics of LAw, supra, at 172 .
} 
individualistic ethic and a healthy distrust of state authority. At worst, they have rested on an anti-communitarian impulse. Often enough, they have rested on both. Given the authorship of these claims, that is not entirely surprising. Those who have most successfully employed the rhetoric of popular constitutionalism and exploited its persuasive potential are not feminists, civil rights activists, environmentalists, anti-poverty workers, or labor organizers. Rather, it is constitutionally-mindful militias, minutemen, gun collectors, hunters, and libertarians that have been most successful in employing popular constitutionalism. Gun collectors fashioned the Second Amendment right to bear $\operatorname{arms}^{47}$ with little or no help from courts, no significant resistance from liberals, ${ }^{48}$ and astounding success in public opinion and the legislature. ${ }^{49}$ Additionally, self-styled "Constitutional Party"

47. For summaries of organizations, individuals, newsletters, think tanks, and blogs supporting the Individual Right to Bear Arms, as well as selling weaponry, see, e.g., Keep and Bear Arms, http://www.keepandBearArms.com (last visited Mar. 27, 2006); 2nd Amendment (Right to Bear Arms), http://www.cato.org/ccs/2nd-Amendment.html (last visited Mar. 27, 2006); Fort Liberty, http://www.fortliberty.org/american-politics/Second-Amendment-gun-control.shtml (last visited Mar. 27,2006 ). There was some early academic commentary feeding this movement, but little proportionate to the movement's success. Further, the academic commentary that followed on the heels of the popular constitutionalists' case for the Second Amendment, made news in the general press and blogosphere. See, e.g., Eugene Volokh, The Mechanisms of the Slippery Slope, 116 HaRv. L. Rev 1026 (2003); William Van Alstyne, The Second Amendment and the Personal Right to Arms, 43 DukE L.J. 1236 (1994).

48. Most resistance to the Second Amendment juggernaut has eome from historians who contest the movement's claims regarding the original meaning of the founding generation. See, e.g., Jon S. Vernick \& Stephen P. Teret, Firearms and Health: The Right to be Armed With Accurate Information about the Second Amendment, 83 AM. J. Pub. Health 1773-77 (1993); David Williams, The Militia Movement and Second Amendment Revolution: Conjuring with the People, 81 CoRnell L. REv. 879 952 (1996) (criticizing and analyzing the constitutional history and arguments of the militia movement); David Williams, Civil Republicanism and the Citizen Militia: The Terrifying Second Amendment, 101 YALE L.J. 551, 563-86 (1991) (providing historical understanding of the second amendment that partially supports and partially undercuts a right to bear arms). But see Glenn Harlan Reynolds, A Critical Guide to the Second Amendment, 62 TENN. L. REv. 461-511 (1995) (arguing for an historical analysis of the Second Amendment that supports an individual right to bear arms). Liberal constitutional scholars, on record for the last twenty or thirty years as eschewing the relevance of history to constitutional meaning, have pcrhaps unsurprisingly shown little taste for the debate over it. There may also be a reluctanee to take on the development of this "Right" because, like so many of the rights favored by liberals, this one is unenumerated. These and other possible explanations for the paucity of liberal scholarship on the Seeond Amendment are explored in Sanford Levinson, The Embarrassing Second Amendment, 99 YALE L.J. 637 (1989).

49. Thus, during the last presidential campaign John Kerry, the democratic candidate and the most "liberal" member of the Senate, repeatedly professed himself a firm believer in the existenee of a Second Amendment Right to Bear Arms. Editorial, Kerry's Nuanced View of Gun Rights, WasH. Times, Sept. 15, 2004, at A22. Although a majority of the public favors gun control laws, the candidates of both parties professed a "belief" in the Seeond Amendment Right to Bear Arms in 2004, the existence of which clearly problematizes such efforts. See HARRIS INTERACTIVE, MAJORITY IN U.S. Favors Stricter Gun CONTROL-But Gun Control is Not Likely to be Much of an Issue in Upcoming Presidential Election (June 16, 2004), http://www.harrisinteractive.com/harris_poll/index.asp?PID $=471$. The House has passed a bill to protect the gun industry from lawsuits for negligence, and has repealed the District of Columbia's gun control laws. Protection of Lawful Commerce in Arms Act, H.R. 1036, 108th Cong. (2003), passed in the House by a 285-140 vote on April 9, 2003, and District of Columbia Personal Protection Act, H.R. 
members support the Minutemen border patrols on constitutional grounds. ${ }^{50}$ In yet another example, tax protestors invoke the purity of their constitutional vision to assert their Jeffersonian right to avoid any and all responsibility for the joint maintenance of the public good. ${ }^{51}$ Of course all of this is changeable. More voices contributing to a popular constitutionalist project might produce a more communitarian, socialistic, progressive, left-leaning popular constitution. But that has not happened, or even been attempted, since the New Deal. The political Left ought to worry about why.

The fourth reservation is procedural, or process-oriented. It is not clear that casting our political disagreements and convictions into the constitutional vision is good for our politics or our communities. Popular constitutionalism is one way to create meaning, and perhaps one way to create community in the process. Siegel's lecture amply proves this point. But is popular constitutionalism an ideal way to create constitutional meaning? The doubt goes not only to the exercise of popular constitutionalism Siegel identified - the creation of the de facto ERA - but to the larger project of popular constitutionalism as well.

There are a number of methodological objections to the invitation to participate in popular constitutionalism posed by Siegel's lecture. The first I will mention only to set it aside: When compared to the constitutional meanings unearthed through adjudicative processes, popular constitutional meaning just does not rank. ${ }^{52}$ Popular constitutional participants lack the prestige, pedigree, and expertise of judicial expositors of the Constitution, causing the constitutional meanings created through political mechanisms

3193, 108th Cong. (2003), repealing D.C.'s gun control laws, passed in the House by $250-171$ on September 29, 2004. The personal right to bear arms protected by the Second Amendment as interpreted by popular constitutionalists has effectively squelched the Gun Control Movement. The Supreme Court had nothing to do with this.

50. See Constitution Party of Missouri, Statements of New Resolutions, http://ConstitutionPartyMo.Org (last visited Mar. 27, 2006).

51. The Constitution Party was called the "Taxpayers Party" until 1999, when it changed its name, but it still subscribes to a firm belief in the unconstitutionality of the federal income tax, the Taxpayers Party's once definitive issue. See Constitution Party (previously, the "Taxpayers Party") National Platform, http://constitutionparty.com/party_platform.php (last visited Mar. 27, 2006). The main goals of the Constitution Party are "to restore American jurisprudence to its Biblical foundations and to limit the federal government to its Constitutional boundaries." Id.

52. In conversation following the Jorde lecture, Dean Jesse Choper asked me whether Professor Siegel's position implies that whenever a portion of the population feels sufficiently agitated about some perceived injustice, the Court should accommodate them by changing the meaning of the Constitution. The worry that popular constitutionalism will degrade the entire enterprise has been a major theme of the critical reaction to Larry Kramer's book on Popular Constitutionalism, with the extreme version of this claim that popular constitutionalism is just a disguise for mob rule. For examples, see Larry Alexander and Lawrence B. Solum, Popular? Constitutionalism?, 118 HARv. L. Rev. 1594 (2005) (reviewing Larry Kramer, The People Themselves: Popular Constitutionalism and Judicial Review (2004)); L.A. Powe, Jr., Are "the People" Missing in Action (and Should Anyone Care)?, 83 TEX. L. REv. 855 (2005) (reviewing KRAMER, supra); Laurence H. Tribe, The People's Court, N.Y. Times, Oct. 24, 2004, at 32 (reviewing KRAMER, supra). 
to lack legitimacy. As such, these new constitutional meanings constitute a threat to legitimate legal precedent in situations where adjudicative and popular constitutional interpretations diverge. Thus the emergent popular constitutionalism has the potential to be an invitation to mob rule; that is, a dangerous invitation to legitimate populist attacks on the Court's authority.

Popular constitutionalists such as Larry Kramer and Mark Tushnet will no doubt respond to this objection in detail, but on its face the claim seems overdrawn. These scholars are not arguing for defiance of Court orders. Popular constitutionalism does not even necessarily constitute a challenge to judicial review or to the Court's role as the ultimate interpreter of the Constitution. Rather, the clear challenge is to the monopoly the Court has over constitutional interpretation. Popular constitutionalism pushes back on the Court's insistence that no other political actor-be it a legislator, the executive, or a citizen-has the right or duty to opine as to the extent and content of our constitutional rights and obligations. In reality, there is no appreciable risk that this challenge to the Court's monopoly will lead to anarchy in the political realm.

The second and relatively unexplored methodological danger in popular constitutionalism, which Siegel's history inadvertently highlights, is not so much that it will induce anarchy or chaos, but rather that it will further freeze political change in a culture already relatively closed to political disputation. Additionally, this danger could occur not just as an unintended consequence, but also precisely because popular constitutionalism is a way to create social meaning. Once constitutionalized, political issues become about the meaning of past events rather than about the contemporary consequences of contemplated policies. This is true with respect to the adjudicated constitution. For example, once the issue of whether states should criminalize abortion was constitutionalized it became a question of whether the right to obtain an abortion is more or less similar to the right to obtain contraception rather than a question of the consequences of abortion policy. Likewise, the same reorientation would attend to popular constitutionalism. Once constitutionalized, questions which might otherwise be argued and decided on the bases of social consequences will instead be argued and decided on the basis of analogy to past history. Consider: If child care is constitutionalized, it is possible the focus of the issue will be on whether and how past constitutional pronouncements might control rather than social consequences such as the appropriate size of income grants to indigents or the most effective way to help women with child care costs. It is not clear that this historical, anti-consequentialist focus is good, either specifically for the cause of universal child care, or more generally for the quality of political discourse.

Given this feature of constitutional discourse, it is not surprising that once the de facto ERA was constitutionalized it emerged as an 
individualistic ethic, stripped of any communal meaning. Indeed, the adjudicated Constitution in which the de facto ERA was absorbed had become a profoundly individualistic, anti-communitarian document by the early 1980 s. Thus, by the time of the de facto ERA's incorporation, the adjudicated Constitution was viewed as a body of law that protects individual rights well and community rights not so well or not at all. (For example, the adjudicated Constitution protects individuals against individual acts of intentional discrimination but does not protect groups against structural or institutional subordination. It promotes individual economic activity through various property related freedoms, but does not necessarily protect groups of economically disadvantaged peoples). Similarly, when political and social struggles were constitutionalized into the de facto ERA those struggles were brought within the ambit of a profoundly individualistic body of law. It is entirely likely that constitutionalizing the contests over legalized abortion, antidiscrimination in employment, and publicly provided childcare furthered rather than challenged the individualistic, anticommunitarian drift of our constitutional narrative.

Relatedly, and like its judicial counterpart, popular constitutionalism relies heavily on American romanticism. The intensely moral and political questions that become constitutional questions through the processes of either adjudicated or popular constitutionalism are answered by reference to narratives drawn from the past. This historical and narrative focus is justified, in turn, because the narratives are our narratives, and when we engage in popular constitutionalism we are not just creating meaning; we are constitutionalizing our meaning of ourselves. Thus we decide whether to support indigents' struggle, or whether to fund child care, abortions for poor women, and health care, not by reference to the budget or the consequences of doing so, but by reference to the stories we tell ourselves about who we are.

This self-focus limits our future to what we glean from the past, and limits our understanding of who we are to our national identity. Thus it can blind us to who we are by virtue of our humanity; that is, our mortality, neediness, and our sympathetic inclination toward others, with a good bit of egoistic attachment to self and some tribal, communitarian, or familial loyalties in between. The focus also blinds us to who we are by virtue of our animalism; that is, vulnerable to pain, cold, hunger, disease, and needful of physical warmth and protection from the bodies of others (as well as their checkbooks). But there are times when we should not be thus blinded; when what should move us when contemplating the extent of our obligations to others is not our shared destiny as Americans, but rather our shared habitation with human beings and other sentient creatures of our endangered planet. 
Third, when and if the meaning of who we are does change by popular constitutional argument, it will do so by virtue of convulsive upheavals. To successfully create meaning in this way-particularly if we aim to change how we see ourselves by using popular constitutionalism-we must revisit deeply held personal and national traits of identity. Taking an example from Siegel's lecture, in order to know whether to provide universal daycare for preschoolers we must first know who we are as a people: a community committed to the well being of our neighbors, or an up-by-thebootstraps confederation of individuals willing to help in a pinch but disinclined to do so as a matter of policy. In these cosmic battles for the country's soul, we risk losing sight of what is at stake in some of these social battles, such as the ideal size of an income grant for indigent women with children and whether the costs of such a program would be worth the benefits. Perhaps we could leave the matter of cultural and national identity to our poets and storytellers. Our politics-including our childcare services, health services, and school systems - might actually improve as a result.

Finally, there are real opportunity costs to constitutionalizing politics. There may be better ways to reach out, to establish community, and to improve our collective lives than by this continual construction of constitutional meaning. Without popular constitutionalism we could speak to each other, not to create and recreate meaning or assert and challenge definitions of self-identity, but instead to express and respond to manifest need. We could engage in the ordinary work of politics more consistently and appreciatively. We could try to recapture the nobility rather than the debasement of ordinary political work. We could work toward the creation of a political consciousness in which we give the past its due, but only its due. Doing so need not require a continual communal struggle over the constitutive identitarian meaning gleaned from it. In short, when we constitutionalize our moral questions we run the real risk of further denigrating and neglecting the ordinary, intensely political work of deliberative democracy and of further entrenching the tendency to view politics as an illegitimate realm of human endeavor.

Constitutional meaning does cast shadows under which ordinary political work proceeds and we must recognize this when it happens. But we must not let a constitutional meaning-such as the antidiscrimination principle embodied in the de facto ERA--becone the ceiling of political progress. When the antidiscrimination principle is understood to exhaust the meaning of equality, as it threatens to do once it becomes a part of our constitutional identity, it becomes an obstacle rather than a vehicle for egalitarian politics. Likewise, on occasion the quest for constitutional meaning through popular constitutional discourse might work against the creation of community through political engagement. 
Given these considerations, should we accept Siegel's implicit invitation to engage in social discourse-and seek social change-by infusing our politics with constitutional meaning? There are very good reasons to do so, the best of which is that the alternative-exclusive, monopolistic, adjudicative constitutionalism-is so bleak. We cannot and should not wholly cede the terrain of constitutional contestation to the legalistic interpretations of courts. There is room for alternative constitutional interpretations in our political discourse. Nevertheless, a frank accounting of the costs associated with such an enterprise is in order. When we engage in constitutional argumentation-on or off the Court, in editorials, in congressional hearings, or in our own living rooms-we ought to do so with caution. The hot flame of constitutional meaning might not be worth the sacrifice of the candle of ordinary, do-it-by-voting politics that the flame might consume. 